\title{
Motivasi Diri Mahaiswa Universitas Negeri Jakarta dalam Menggunakan Media Sosial
}

\author{
Vera Wijayanti Sutjipto, Fahira Novanra \\ Program Studi Ilmu Komunikasi, Fakultas Ilmu Sosial, Universitas Negeri Jakarta \\ Email: verawijayanti@unj.ac.id
}

DOI: https://doi.org/10.21107/ilkom.v14i2.8089

\begin{abstract}
ABSTRAK
Penggunaan media sosial bagi setiap orang berbeda, bergantung dari motivasi penggunaannya. Penelitian ini bertujuan untuk mengetahui motivasi diri mahasiswa Universitas Negeri Jakarta dalam menggunakan media sosial. Teori yang digunakan pada penelitian ini adalah teori motivasi diri dengan dua dimensi yakni dimensi kekuatan dari individu dan dimensi kebutuhan yang tidak terpenuhi sebagai motivasi dari menggunakan media sosial. Metode penelitian dalam penelitian ini adalah metode penelitian kuantitatif deskriptif menggunakan kuesioner sebagai alat pengumpulan data primer kepada 80 orang responden yang telah memenuhi kriteria penelitian yaitu mahasiswa aktif Universitas Negeri Jakarta angkatan 2019 dan memiliki akun sosial media. Hasil penelitian ini menunjukan bahwa motivasi mahasiswa Universitas Negeri Jakarta dalam menggunakan media sosial adalah a) keinginan dari individu sendiri yang dipengaruhi oleh orang lain dengan tujuan dasar untuk mengikuti perkembangan zaman, b) untuk memenuhi kebutuhan sosiologis berupa komunikasi dengan orang lain tanpa mengenal batasan jarak dan waktu, kebutuhan untuk terus menjalin silahturahmi, kebutuhan untuk mengenal orang baru dan kebutuhan untuk mencari serta mendapat teman dan juga kebutuhan untuk mendapat berbagai informasi terkini yang sedang diperbincangkan dalam masyarakat.
\end{abstract}

Kata kunci : motivasi diri, media sosial, mahasiswa

\section{ABSTRACT}

Usability of media sosial was different for each person, depending on the motivation to use it. This study aims to determine the self-motivation of Jakarta State University students in using social media. The theory used in this research is the motivation theory with two dimensions, namely the dimensions of the strength of the individual and the dimensions of unmet needs as motivation from using social media. The research method in this study is a descriptive quantitative research method using a questionnaire as a primary data collection tool for 80 respondents who have met the research criteria, that is active students of Jakarta State University class 2019 and have social media accounts. The results of this study indicate that the motivation of the Jakarta State University students in using social media is a) the desire of the individual himself who is influenced by others with the basic aim of keeping up with the times, $b$ ) to meet sociological needs in the form of communication with others without knowing the boundaries of distance and time, the need to keep in touch with people, the need to get to know new people and the need to find and make friends and also the need to get the latest information that is being discussed in society.

Keywords : self-motivation, social media, students.

\section{Cite this as :}

Sutjipto, Vera Wijayanti dan Fahira Novanra. (2020). Motivasi Diri Mahaiswa Universitas

Negeri Jakarta dalam Menggunakan Media Sosial. Jurnal Komunikasi, 14(2), 149-160. Doi :

https://doi.org/10.21107/ilkom.v14i2.8089

Article History :

Received August, $2^{\text {th }}$ 2020,

Acepted September, $3^{\text {th }} 2020$ 


\section{PENDAHULUAN}

Kaplan dan Haenlein (2010: 60) berpendapat bahwa media sosial tersendiri merupakan beberapa kumpulan dari berbagai aplikasi aplikasi yang dibuat berbasisBBBBBBBBBBBB internet, dan berlandaskan pada ideologi maupun teknologi yang di sebut Web 2.0 yang mana teknologi ini dapat memungkinkan penciptaan ataupun adanya pertukaran pesan, informasi maupun konten dari para penggunanya. Selain itu, media sosial juga merupakan suatu platform yang mana penggunanya dapat dengan mudah membuat akun, kemudian mampu berkomunikasi atau terhubung dengan orang lain dalam platform tersebut. Akun tersebut dapat diakses oleh orang lain tanpa terbatas oleh jarak. Hal ini membuktikan bahwa media sosial tidak ada batasan jarak untuk saling terhubung dan bersosialisasi atau berinteraksi (Mustafa, 2010: 38).

Berbagai penelitian telah menunjukan bahwa media sosial lebih aktif digunakan oleh manusia pada era ini, tak terkecuali oleh masyarakat Indonesia. Pada tahun 2020, We Are Social memberikan laporan bahwa terdapat total.175,4 juta orang yang menggunakan internet di tanah air, yang menandakan bahwa terdapat peningkatan penggunaan dari tahun tahun sebelumnya (Haryanto,2020).

Pengguna aktif media sosial di Indonesia sendiri terdiri dari berbagai jenjang usia dan generasi. Hal ini dibuktikan dari laporan APJII yang mengatakan bahwa generasi anak muda yang disebut sebagai milenial merupakan pengguna aktif dari media sosial di Indonesia pada masa kini, dengan penetrasi sekitar 88,5\%. Lalu disusul oleh kelompok umur lainnya, mulai dari sekitar usia 25 hinggaa 29 tahun memiliki pendekatan $82,7 \%$, lalu 30 hingga 34 tahun memiliki penetrasi yang bernilai $76,5 \%$, dan terakhir adalah kelompok 35 hingga 39 tahun dengan penitrasi paling kecil yaitu $68,5 \%$ (Haryanto, 2019). Berdasarkan data tersebut, dapat dilihat bahwa generasi milenial telah mendominasi penggunaan media sosial karena paling aktif dalam menggunakannya.
Adapun yang disebut sebagai generasi tersebut adalah kaum muda seperti mahasiwa.

Aktif-nya penggunaan media sosial di kalangan mahasiswa didasari oleh berbagai alasan yang menjadi motivasi maupun tujuan mahasiswa dalam menggunakan media sosial tersebut. Motivasi penggunaan media sosial telah di kategorikan dalam beberapa kategori kelompok tujuan yakni menjadikan media tersebut untuk memenuhi keinginan maupun ketertarikan, menghabiskan waktu, interaksi sosial, hiburan, mendapat informasi maupun pembelajaran (Morissan, 2010: 84). Tentunya motivasi penggunaan media sosial tersebut berbeda-beda dari setiap orang. Ada yang menggunakan media sosial untuk ajang aktualisasi diri, dan ada pula yang menggunakannya untuk mencari teman, bertahan hidup, ingin lebih bersosialisasi, ataupun lebih di hargai. Motivasi tersebut merupakan motif informasi, motif hiburan, motif bisnis dan motif aktualisasi diri (Alfindra \& Yahya, 2017: 9). Berbagai motivasi yang melatarbelakangi penggunaan media sosial tersebut menjadi dasar penelitian ini yaitu untuk mengetahui motivasi diri mahasiswa khususnya mahasiswa UNJ dalam menggunakan media sosial.

Sebelum penelitian ini dibuat, terdapat beberapa peneliti terdahulu yang mencoba mengkaji variabel yang sama. Adapun penelitian yang dilakukan oleh peneliti sebelumnya sebagai berikut :

Pertama, Penelitian yang dilakukan oleh Muhammad Furqan Alfindra dan Martunis Yahya tahun 2017 dengan judul penelitian "Motivasi Mahasiswa Bergabung Dalam Media Sosial Instagram (Studi Pada Mahasiswa Jurusan Ilmu Komunikasi FISIP Unsyiah yang Menggunakan Instagram)". Tujuan dari penelitian tersebut adalah untuk mengetahui motivasi mahasiswa menggunakan sosial media yaitu instagram. Penelitian dilakukan dengan metode kualitatif deskriptif dan menggunakan teori Uses and gratification dan teori Motivasi dari Abraham H. Maslow. Penelitian menggunakan teknik penggumpulan data erupa wawancara terstruktur dan studi dokumentasi kepada 6 
informan terpilih. Dari penelitian tersebut mendapat beberapa temuan bahwa motif penggunaan media sosial oleh mahaiswa adalah motif informasi, hiburan, aktualisasi dri dan bisnis.

Penelitian selanjutnya adalah penelitian yang dilakukan oleh Beny Setiyo Nugroho tahun 2014 dengan judul penelitian "Motivasi Penggunaan Facebook oleh Mahasiswa di Jember". Tujuan dari penelitian tersebut untuk mengetahui motivasi penggunaan facebook oleh mahasiswa di kota jember, mengetahui aktivitas sosial serta fenomena yang sedang berkembang di media sosial tersebut. Penelitian menggunakan Teori Mind, Self, Society dari Herbert Meadserta teori motivasi yang dikemukakan oleh Murray dan Teori Komunikasi Source, Message, Channel Receiver. Sedangkan metode penelitian yang dilakukan adalah metode deskriptif kualitatif dengan teknik pengumpulan data melalui observasi, wawancara mendalam serta dokumentasi. Dari penelitian ini mendapatkan temuan bahwa motivasi dari penggunaan facebook adalah untuk pemenuhan kebutuhan akan hiburan (rasa senang), pemuas indra, motivasi bisnis, motivasi pendidikan motivasi organisasi, dan motivasi spiritual.

Berbeda dengan penelitian sebelumnya yang lebih terpaku pada metode penelitian kualitatif, dalam penelitian ini peneliti menggunakan metode penelitian kuantitatif deskriptif guna mendapatkan data yang lebih sistematis, faktual dan akurat. Selain itu, pada penelitian ini peneliti menggunakan Teori Motivasi yang di kemukakan oleh Gibson yang merumuskan bahwa motivasi sebagai suatu dorongan, yang disebabkan oleh berbagai faktor seperti dalam maupun luar, guna mencapai tujuan tertentu untuk pemenuhan dan pemuasan kebutuhan (Prihartanta, 2015: 1).

Motivasi sendiri (dalam Gibson, 2007:185) merupakan konsep yang menjelaskan mengenai kekuatan-kekuatan yang terdapat pada diri individu, dimana tujuannya sebagai berikut: a) Untuk mendorong individu dan,

b) Mengarahkan perilaku individu.

Motivasi itu timbul diawali dengan adanya berbagai kebutuhan - kebutuhan yang mungkin tidak terpenuhi. Kebutuhan yang mungkin tidak dapat terpenuhi tersebut dapat terdiri dari berbagai hal. Adapun kebutuhan yang yang di maksud (dalam Gibson et,al, 2005:139), sebagai berikut:

a) Kebutuhan Fisiologis

Kebutuhan fisiologis dapat diartikan sebagai sebuah kebutuhan yang paling utama bagi semua manusia guna mempertahankan hidupnya. Kebutuhan ini terdiri akan sandang dan pangan yaitu kebutuhan tempat tinggal, makanan, minuman, tidur, serta udara.

b) Kebutuhan sosiologis

Kebutuhan sosiologis merupakan kebutuhan manusia untuk berinteraksi dengan manusia lainnya. Kebutuhan sosilogis ini dapat disebut pulakebutuhan sosial karena mencakup kebutuhan akan rasa seperti rasa memiliki atau dimiliki, rasa kepercayaan, rasa kasih sayang dan cinta.

c) Kebutuhan psikologis

Kebutuhan psikologis merupakan kebutuhan manusia akan pengakuan, aktualisasi diri atau harga diri di depan manusia lain.

Motivasi dapat dikatakan sebagai sebuah gejala psikologis berupa dorongan yang ditimbulkan dalam diri seseorang guna melakukan berbagai upaya untuk tujuan yang telah diharapkan. Motivasi itu juga dapat menyebabkan seseorang melakukan suatu tujuan yang diinginkan guna mendapat kepuasan dari perbuatannya (Prihartanta, 2015: 3).

\section{METODE PENELITIAN}

Penelitian menggunakan paradigma kualitatif dengan metode studi kasus di di Biro Fasilitasi Kebijakan Energi dan 
Persidangan Setjen DEN. Data terdiri dari data primer dan data sekunder. Pengumpulan data primer dilakukan dengan wawancara terhadap key informants. Data sekunder dengan melakukan peninjauan literatur, seperti jurnal, buku dan peraturan terkait. Penelitian menggunakan analisis prinsip yang mempengaruhi iklim organisasi yang disampaikan Higgins (1994) dan strategi komunikasi yang disampaikan Cangara (2018).

Selanjutnya, analisis data dengan cara, yaitu pertama, pengumpulan data untuk memperolah informasi berupa kalimatkalimat yang dikumpulkan melalui wawancara, observasi dan tinjauan literatur. Kedua, mereduksi data, dengan merangkum, memilah dan memfokuskan pada hal yang sesuai dengan bahasan dan mencari tema yang tepat untuk gambaran yang lebih jelas.

Ketiga, menyajikan data dengan mengorganisasi data dan menyusun pola yang berhubungan sehingga lebih mudah dipahami. Keempat, penarikan kesimpulan. Untuk menarik kesimpulan dari data yang ada melalui pola keteraturan pada iklim komunikasi organisasi dan strategi komunikasi di di Biro Fasilitasi Kebijakan Energi dan Persidangan Setjen DEN.

\section{Pemilihan key informants}

berdasarkan jabatan di lingkungan Biro Fasilitasi Kebijakan Energi dan Persidangan Setjen DEN, baik itu Pimpinan Tinggi Pratama Kepala Biro, Pejabat Administrator Kepala Bagian, Pejabat Pengawas Kepala Sub Bagian maupun Pejabat Pelaksana. Key informants dimaksud yaitu Kepala Biro Fasilitasi Kebijakan Energi dan Persidangan, Kepala Sub Bagian Fasilitasi Kebijakan Penyediaan Energi, Kepala Sub Bagian Keprotokolan, Kepala Sub Bagian Dokumentasi, Pengadministrasi Data dan Protokol yang diwawancarai pada tanggal 30 Oktober 2019, Kepala Bagian Fasilitasi Rencana Umum Energi yang diwawancarai pada tanggal 1 November 2019, dan Kepala Sub Bagian Humas pada tanggal 10 November 2019.
Berikut daftar key informants seperti di bawah ini:

TABEL 1.

DAFTAR KEY INFORMANTS

\begin{tabular}{|c|c|c|}
\hline $\begin{array}{l}\mathbf{N} \\
\mathbf{o} .\end{array}$ & $\begin{array}{c}\text { Key } \\
\text { Informants }\end{array}$ & Tugas \\
\hline & $\begin{array}{l}\text { Kepala Biro } \\
\text { Fasilitasi } \\
\text { Kebijakan } \\
\text { Energi dan } \\
\text { Persidangan }\end{array}$ & $\begin{array}{l}\text { Membantu Sekretaris Jenderal } \\
\text { DEN dalam penyelenggaraan } \\
\text { persidangan, penyiapan dan } \\
\text { pengelolaan } \\
\text { persidangan DEN dalam rangka } \\
\text { perancangan dan perumusan } \\
\text { KEN dan penetapan RUEN, } \\
\text { penyelenggaraan Humas }\end{array}$ \\
\hline 2. & $\begin{array}{l}\text { Kepala } \\
\text { Bagian } \\
\text { Fasilitasi } \\
\text { Rencana } \\
\text { Umum } \\
\text { Energi }\end{array}$ & $\begin{array}{l}\text { Melaksanakan penyiapan bahan } \\
\text { perencanaan energi untuk } \\
\text { fasilitasi penyelenggaraan } \\
\text { persidangan DEN }\end{array}$ \\
\hline 3. & $\begin{array}{l}\text { Kepala Sub } \\
\text { Bagian } \\
\text { Fasilitasi } \\
\text { Kebijakan } \\
\text { Penyediaan } \\
\text { Energi }\end{array}$ & $\begin{array}{l}\text { Melakukan penyiapan bahan, } \\
\text { data dan penelaahan, serta } \\
\text { evaluasi pelaksanaan atas } \\
\text { penyiapan perumusan kebijakan } \\
\text { energi di sisi penyediaan energi }\end{array}$ \\
\hline 4. & $\begin{array}{l}\text { Kepala Sub } \\
\text { Bagian } \\
\text { Keprotokolan }\end{array}$ & $\begin{array}{l}\text { Melakukan penyusunan bahan, } \\
\text { data dan penelaahan, serta } \\
\text { evaluasi pelaksanaan atas } \\
\text { penyelenggaraan keprotokolan } \\
\text { yang meliputi penyiapan jadwal, } \\
\text { agenda, undangan dan } \\
\text { penyelenggaraan persidangan } \\
\text { DEN }\end{array}$ \\
\hline 5. & $\begin{array}{l}\text { Kepala Sub } \\
\text { Bagian } \\
\text { Dokumentasi }\end{array}$ & $\begin{array}{l}\text { Melakukan penyusunan bahan, } \\
\text { data dan penelaahan, serta } \\
\text { evaluasi pelaksanaan atas } \\
\text { dokumentasi persidangan dan } \\
\text { penyusunan notulen persidangan } \\
\text { DEN }\end{array}$ \\
\hline
\end{tabular}

6. Kepala Sub Melakukan pengumpulan bahan Bagian dan data, pelaksanaan, serta Humas evaluasi pelaksanaan atas penyelenggaraan komunikasi kemasyarakatan, siaran dan konferensi pers, publikasi dan hubungan kelembagaan kegiatan DEN

7. Pengadminis Membantu penyusunan bahan, trasi Data data dan penelaahan, serta evaluasi pelaksanaan dokumentasi persidangan DEN

8. Protokol Membantu penyusunan bahan, data dan penelaahan, serta evaluasi pelaksanaan atas penyelenggaraan keprotokolan persidangan DEN

Sumber: Diolah dari Permen ESDM Nomor 14 Tahun 2009 tentang Tugas dan Fungsi Organisasi Setjen DEN 


\section{HASIL DAN PEMBAHASAN}

Biro Fasilitasi Kebijakan Energi dan Persidangan Setjen DEN menyelenggarakan fungsi (1) koordinasi persidangan DEN, (2) pengelolaan fasilitasi kegiatan Kelompok Kerja, (3) pengelolaan kajian kebijakan dan perencanaan energi, (4) penyusunan bahan persidangan untuk perumusan KEN, (5) penyusunan bahan persidangan untuk penelaahan atas rumusan RUEN yang disiapkan oleh Pemerintah, serta perencanaan energi daerah, (6) penyelenggaraan persidangan dan penyusunan notulen persidangan DEN, (7) penyelenggaraan keprotokolan dan kehumasan DEN dan (8) evaluasi dan pelaporan fasilitasi persidangan untuk penyusunan bahan perumusan KEN dan penetapan Rencana Umum Energi.

Biro Fasilitasi Fasilitasi Kebijakan Energi dan Persidangan Setjen DEN terdiri dari tiga bagian dan satu kelompok jabatan, yaitu (1) Bagian Fasilitasi Kebijakan Energi, (2) Bagian Fasilitasi Rencana Umum Energi, (3) Bagian Humas dan Persidangan (4) Kelompok Jabatan Fungsional.

Bagian Fasilitasi Kebijakan Energi mempunyai tugas melaksanakan penyiapan bahan persidangan kebijakan energi untuk fasilitasi penyelenggaraan persidangan DEN dan kegiatan Kelompok Kerja. Dalam melaksanakan tugas sebagaimana dimaksud, bagian Fasilitasi Kebijakan Energi menyelenggarakan fungsi (1) penyiapan koordinasi untuk penyusunan bahan persidangan kebijakan energi, (2) pelaksanaan kajian untuk perancangan kebijakan energi, (3) penyiapan bahan untuk perancangan kebijakan energi dalam persidangan DEN dan kegiatan Kelompok kerja, dan (5) evaluasi dan pelaporan pelaksanaan penyiapan bahan persidangan kebijakan energi untuk fasilitasi penyelenggaraan persidangan DEN dan kegiatan kelompok kerja.

Bagian Fasilitasi Rencana Umum Energi mempunyai tugas melaksanakan penyiapan bahan perencaan energi untuk fasilitasi penyelenggaraan persidangan DEN dan kegiatan Kelompok Kerja. Dalam melaksanakan tugas sebagaimana dimaksud, Bagian Fasilitasi Rencana Umum Energi menyelenggarakan fungsi (1) penyiapan koordinasi untuk penyusunan bahan persidangan perencanaan energi, (2) pelaksanaan kajian perencanaan energi nasional dan daerah, (3) penyiapan bahan penyusunan rancangan RUEN, (4) penyiapan bahan untuk penelaahan neraca energi, dan (5) evaluasi dan pelaporan pelaksanaan penyiapan bahan perencanaan energi untuk fasilitasi penyelenggaraan persidangan Dewan Energi Nasional dan kegiatan Kelompok Kerja.

Bagian Humas dan Persidangan memiliki tugas melaksanakan urusan humas, keprotokolan, dan persidangan DEN, serta kegiatan Kelompok Kerja. Dalam melaksanakan tugas sebagaimana dimaksud, Bagian Humas dan Persidangan menyelenggarakan fungsi (1) penyiapan koordinasi penyelenggaraan humas dan persidangan, (2) pelaksanaan keprotokolan Sidang Paripurna dan Sidang Anggota DEN, serta kegiatan Kelompok Kerja, (3) pelaksanaan fasilitasi Sidang Paripurna dan Sidang Anggota DEN, serta kegiatan Kelompok Kerja, (4) pelaksanaan humas dan hubungan kelembagaan, (5) pelaksanaan dokumentasi dan pengumpulan bahan persidangan DEN, serta kegiatan Kelompok Kerja, (6) Penyusunan notulen persidangan DEN, dan (7) evaluasi dan pelaporan pelaksanaan humas keprotokolan, dan persidangan DEN, serta kegiatan Kelompok Kerja.

Biro Fasilitasi Kebijakan Energi dan Persidangan memiliki jumlah pegawai sebanyak dua puluh sembilan orang, dengan paling banyak menduduki Golongan/Ruang III/b yaitu sepuluh orang. Setelah itu Golongan/Ruang III/d sebanyak enam orang, Golongan/Ruang III/c sebanyak lima orang, Golongan/Ruang IV/b, III/a, dan II/d masingmasing sebanyak dua orang, serta Golongan/Ruang IV/c dan IV/a masingmasing sebanyak satu orang. 
TABEL 2.

GOLONGAN/ RUANG PEGAWAI DI BIRO
FASILITASI KEBIJAKAN ENERGI DAN
PERSIDANGAN SETJEN DEN

\begin{tabular}{|c|c|c|}
\hline No. & Golongan/Ruang & Jumlah \\
\hline 1. & $\mathrm{II} / \mathrm{d}$ & 2 orang \\
\hline 2. & III/a & 2 orang \\
\hline 3. & $\mathrm{III} / \mathrm{b}$ & 10 orang \\
\hline 4. & $\mathrm{III} / \mathrm{c}$ & 5 orang \\
\hline 5. & $\mathrm{III} / \mathrm{d}$ & 6 orang \\
\hline 6. & $\mathrm{IV} / \mathrm{a}$ & 1 orang \\
\hline 7. & $\mathrm{IV} / \mathrm{b}$ & 2 orang \\
\hline 8. & $\mathrm{IV} / \mathrm{c}$ & 1 orang \\
\hline To & & 29 orang \\
\hline
\end{tabular}

Sumber: Diolah dari Data Kepegawaian per 1 Oktober 2019

Iklim Komunikasi Organisasi di Biro Fasilitasi Kebijakan Energi dan Persidangan dapat dijelaskan seperti di bawah ini. Pertama, pimpinan dalam hal ini adalah Pimpinan Tinggi Pratama Kepala Biro, Pejabat Administrator Kepala Bagian, Pejabat Pengawas Kepala Sub Bagian di lingkungan Biro Fasilitasi Kebijakan Energi dan Persidangan. Menurut Kepala Bagian Fasilitasi Rencana Umum Energi:

"Karo (Kepala Biro) memberikan
perintah (di Grup WhatsApp), singkat,
sangat minimalis, (sehingga perlu)
klarifikasi. Memberikan motivasi dari
sisi yang berbeda. Kita tidak
terpikirkan ada gambaran, ide baru.
Bagus, kreatif, dan ingin maju bikin
saja. Cukup mendorong, kreatif.
(Sedangkan) masih belum jalan,
reward belum (jalan).

Kepala Sub Bagian Penyediaan Energi menjelaskan:

"Sepertinya (Kepala Biro) lebih
persuasif, meeting bareng. (Untuk)
reward masih kurang (dijalankan),
punishment (sudah) jalan karena
sistem jalan seperti itu. Gaya
komunikasi lebih merangkul, ketika
keluar kita adalah Biro II (Biro
Fasilitasi Kebijakan Energi dan
Persidangan) secara utuh."

Kepala Sub Bagian Dokumentasi, Kepala Sub Bagian Humas, Protokol dan Pengadministrasi Data menyampaikan bahwa tidak berjalannya reward di Biro Fasilitasi Kebijakan Energi dan Persidangan. Sementara itu, Kepala Sub Bagian Keprotokolan menyampaikan bahwa Kepala Biro Fasilitasi Kebijakan Energi dan Persidangan memotivasi pegawai di bawahnya.

\section{"Berusaha men-trigger kita. Yuk, kita bikin input apa, walaupun kondisi kita saat ini. Ada willingness."}

Ia menambahkan bahwa cara dirinya memberikan motivasi kepada pegawai di bawahnya adalah dengan menjelaskan mengenai dedikasi sebagai Apratur Sipil Negara (ASN):

"Once, kita sudah menentukan pilihan kita menjadi PNS (Pegawai Negeri Sipil), artinya, itu sudah jalan kita. Walaupun, kadang-kadang semangat itu didukung dengan adanya pendapatan dan pemasukkan. Kembali lagi, ada atau tidak ada tambahan, tetap kita digaji negara. Mencoba untuk membangun, yuk kita ini memang mendedikasikan diri menjadi ASN. Tunjukkan itu kita ada beban moral. Kalau tidak mau di sini, keluar."

Kedua, Tingkah Laku Pegawai. Kepala Biro Fasilitasi Kebijakan Energi dan Persidangan menyampaikan:

"Ini kita masih terkotak-kotak, per Bagian. Ini tidak campur. Milenial dan non milenial. Generasi sebenarnya, bukan masalah pekerjaan/ jabatan. Ini yang harus semua juga bisa menyadari dulu bahwa kita beda generasi, the way how to-nya berbeda. Kedua, per Bagian beda-beda (tugas dan fugsi). Kegiatan saling mengetahui, kalau tidak secara dalam, paling tidak mengetahui, tugas fungsi seperti apa. Apakah diimplementasikan, belum tentu. Kita pro aktif, karena pekerjaan harus pro aktif, kalau jaman sekarang."

Kepala Bagian Fasilitasi Rencana Umum Energi menyampaikan komunikasi sudah berjalan dengan baik, hanya saja ada beberapa orang yang cara berkomunikasinya tidak berjalan secara dua arah, jelasnya: 
"Harusnya demokrasi. Ada satu-dua orang yang mendominasi. Kalau saya, lebih baik menghindar. Kalau (orang seperti itu) dihadapi, (berpotensi) menimbulkan polemik, lebih baik polemik itu ditinggalkan. (Lebih baik) kita berkomunikasi dengan orang lain yang sejalan, (agar) lebih produktif."

Lain halnya apa yang disampaikan oleh Kepala Sub Bagian Humas, menurutnya tidak hanya dalam satu Biro, bahkan ada Pelaksana yang masih berjalan sendirisendiri. Berjalan sendiri-sendiri yang dimaksud adalah belum menjalankan komunikassi organisasi secara maksimal.

Sejalan dengan itu, Kepala Sub Bagian Keprotokolan menjeaskan hal itu normatif dan wajar:

"Manusiawi, ada yang berkerja berdasarkan tanggung jawab, ada yang berkerja berdasarakan uang, saja. (Saya berharap) Biro II (Biro Fasilitasi Kebijakan Energi dan Persidangan) lebih kekeluargaan."

Kepala Sub Bagian Penyediaan Energi, Protokol dan Pengadministrasi data menjelaskan untuk menekankan pentingnya koordinasi. Lebih lanjut Kepala Sub Bagian Penyediaan Energi:

"Misalnya kita terkait kebutuhan
(organisasi), (bisa) berkoordinasi
dengan bidang lain, (untuk) menyiapkan
bahan. Paling kita berkoordinasi, mana
yang dipakai. Tidak masalah, tidak
merasa ada gap (antar pergawai).

Ketiga, Tingkah Laku Kelompok Kerja. Kepala Biro Fasilitasi Kebijakan Energi dan Persidangan menyampaikan:

"Semua (antar Bagian masih) terkotakkotak. (Walaupun) ada plus-minus, dalam perkerjaan tidak boleh terkotakkotak. Tatkala menyelesaikan perkerjaan tidak ada yang terkotakkotak, solid dan solved. Saling melihat kiri-kanan. (Jangan) seperti kacamata kuda. Hal yang seperti itu kita buang, kita harus satu tim."
Kepala Sub Bagian Keprotokolan menambahkan mengenai tingkah laku kelompok secara formal di Biro Fasilitasi Kebijakan Energi dan Persidangan:

"Secara formal, masih belum
maksimal. Secara formal, (masih)
terkotak-kotak. Bagian Humas dan
Persidangan sendiri kerjanya. Bagian
Fasilitasi Rencana Umum Energi
sendiri kerjanya. Bagian Fasilitasi
Kebijakan Energi sendiri kerjanya.
Tidak saling guyub. (Seharusnya bisa
dibangun kekompakkan) apa yang bisa
kita support dari sini, apa yang bisa
kita support dari sana."

Kepala Bagian Fasilitasi Rencana Umum Energi menjelaskan hal berbeda:

"Bagian Fasilitasi Kebijakan Energi sudah berjalan baik (tingah laku kelompok), komunikasi sudah tektok (dua arah). Kalau tidak ada yang tahu, (yang lain) memberi tahu. Kalau berdasarkan pemintan (informal), itu lebih jalan, (seperti) hobi."

Kepala Sub Bagian Keprotokolan memandang tingkah laku kelompok secara informal sudah berjalan baik:

\footnotetext{
"(Untuk yang) perempuan kadang makan siang bareng. Laki-laki futsal bareng. (Walaupun) ada yang tidak kompak, satu-dua (orang)."
}

Pengadministrasi Data menyampaikan di salah satu Bagian di lingkungan Biro Fasilitasi Kebijakan Energi dan Persidangan belum terbangun kekompakkan dalam tim:

"Masih ada selisih paham. Tidak
berbaur (antar anggota Bagian).
(Upaya untuk membuat kompak salah
satunya adalah) sering jalan bareng."

Kepala Sub Bagian Penyediaan Energi menjelaskan bahwa untuk mendorong motivasi antar anggota Bagian perlu memberikan reward:

"Harus mendorong mereka supaya lebih baik lagi (dalam bekerja). Harus 
didorong, dikasih motivasi, termasuk reward."

Kepala Sub Bagian Humas mengungkapkan saat ini perkerjaan yang dikerjakan relatif lebih fleksibel. Hal yang berbeda di unit kerja sebelumnya:

\section{"Jangankan (untuk) mengobrol, (bahkan, waktu untuk) makan kadang lupa."}

Keempat, Faktor Eksternal Organisasi. Kepala Biro Fasilitasi Kebijakan Energi dan Persidangan berpandangan dengan organisasi yang masih terkotakkotak, Ia menjelaskan bahwa cara untuk mengelola organisasi adalah dengan seni kepemimpinan:

"Sebagai pimpinan yang berat itu
mengatur ini (faktor eksternal:
keuangan). Anggaran APBN (Anggaran
pendapatan dan Belanja Negara)
seratus persen untuk kerja. Itu adalah
art(seni)dari situ (untukbisa mengelola
keuangan).

Kepala Bagian Fasilitasi Rencana Umum Energi menyikapi dengan turunnya alokasi anggaran dari tahun anggaran sebelumnya tidak menurunkan semangat pegawai dalam bekerja:

\section{"Tupoksi (tugas, pokok dan fungsi)-nya ada. (Pada Bagian Humas dan Persidangan) fungsi kehumasan tetap jalan, (tetap) membuat berita. Ada sesuatu yang dihasilkan. PNS dibayar sesuai dengan tusi (tugas dan fungsi)- nya."}

Dengan adanya penurunan anggaran pada tahun anggaran 2019, Kepala Sub Bagian Keprotokolan mengungkapkan bahwa memiliki efek terhadap produktivitas kerja:

"Kita bekerja berbasis anggaran. Kinerja, anggaran dan output. Output jadi tidak banyak. Produktifitas (tetap) maksimal, tapi tidak banyak apa yang bisa kita hasilkan. Apapun yang kita kerjakan maksimal, tapi output tidak sebanyak dulu. Dengan output tidak banyak, pekerjaan tidak banyak, jadi kurang produktif. Produktivitas
menurun."

Kepala Sub Bagian Penyediaan Energi mengungkapkan bahwa dengan penurunan anggaran dari tahun sebelumnya tetap bersama-sama dalam tim untuk bekerja dengan maksimal. Untuk itu lebih memilih untuk mempersuasi dan memotivasi anggota timnya untuk dapat berkerja secara masksimal:

"Lebih banyak persuasi dan motivasi. Memang keadaan seperti ini, (namun tetap) kita bersama-sama dalam satu tim (secara maksimal)."

Protokol menyebutkan bahwa kesejahteraan sangat diidamkan para pegawai. Bahkan, ia menjelaskan bahwa faktor ekonomi, dapat mempengaruhi pikiran pegawai:

"Intinya ada kesejahteraan. Manusia
menjadi rampok, manusia menjadi
maling, manusia menjadi pembunuh, itu
faktor ekonomi, karena keuangan.
Kesejahteraan bisa mempengaruhi
pikiran."

Pada strategi Komunikasi di Biro Fasilitasi Kebijakan Energi dan Persidangan dapat dijelaskan, yaitu pertama, penetapan komunikator. Kepala Sub Bagian Keprotokolan menjelaskan pimpinan teratas (Kepala Biro Fasilitasi Kebijakan Energi dan Persidangan yang dapat menyatukan setiap pegawai di Biro Fasilitasi Kebijakan Energi dan Persidangan. Pengadministrasi data menyampaikan hal serupa bahwa leader (pimpinan) dapat mempersatukan seluruh pegawai, sehingga tidak terkotak-kotak lagi.

Sedangkan, Kepala Sub Bagian Humas menyampaikan bahwa Pejabat Administrator Kepala Bagian diperbolehkan untuk menyampaikan informasi, ini adalah fungsi Bagian Humas dan Persidangan. Pimpinan di sini, baik itu Kepala Biro Fasilitasi Kebijakan Energi dan Persidangan, Kepala Bagian Humas dan Persidngan, Kepala Bagian Fasilitasi Kebijakan Energi dan Persidangan, Kepala Bagian Fasilitasi Rencana Umum Energi. Maupun Kepala Sub 
Bagian Dokumentasi, Kepala Sub Bagian Keprotkolan, Kepala Sub Bagian Humas, Kepala Sub Bagian Penyediaan Energi, Kepala Sub Bagian Pemanfaatan Energi, Kepala Sub Bagian Fasilitasi RUEN, dan Kepala Sub Bagian Pemantauan Pelaksanaan RUEN.

Kedua, Penetapan Target. Target yang ditetapkan adalah seluruh pegawai di lingkungan Biro Fasilitasi Kebijakan Energi Persidangan. Khususnya, pegawai yang memang dianggap belum memiliki kerja sama yang baik, walaupun hanya satu-dua pegawai saja.

Namun, Kepala Sub Bagian Humas menyampaikan:

\begin{abstract}
"Seharusnya yang namanya kebijakan seluruh masyarakat harus tahu. Maka dari itu, setiap peraturan perundangan (setelah) diundangkan setiap masyarakat wajib mengetahui atau dianggap mengetahui."
\end{abstract}

Ketiga, Menyusun Pesan. Kepala Sub Bagian Humas menyampaikan bahwa pesan yang disusun merupakan setidaknya keberadaan kebijakan dan dapat dipastikan ada hal-hal yang bersifat kewajiban dan larangan. Kebijakan yang disampaikan dapat berupa arahan Pimpinan, tindak lanjut hasil pembahasan rapat, sampai dengan peraturan perundangan yang sudah ditetapkan oleh Pemerintah.

Kepala Sub Bagian Keprotokolan menjelaskan jika sistem bisa dirubah, manajerial atau ketata-laksanaannya dirubah dapat membuat maksimal pelaksanaan tugas dan fungsi setiap Bagian di lingkungan Biro Fasilitasi Kebijakan Energi dan Presidangan. Namun, demikian dengan merubah manajerial memerlukan proses dan waktu yang bertahap dan tidak singkat.

Keempat, pemilihan media dan saluran komunikasi. Kepala Sub Bagian Humas menyampaikan bahwa media yang digunakan adalah media elektronik dan online yang efektif. Protokol menjelaskan bahwa rapat dapat dijadikan sarana untuk berkomunikasi setiap Bagian untuk membahas tentang perencanaan energi seperti Outlook Energi Indonesia, dan Kajian tentang energi yang diikuti oleh ketiga Bagian.

Media komunikasi yang digunakan yaitu berupa media percakapan seperti aplikasi WhatsApp, baik itu jalur pribadi (japri) maupun grup percakapan Biro Fasilitasi Kebijakan Energi dan Persidangan. Media daring bisa melalu surat elektronik (email) baik itu melalui e-mail den.go.id, esdm.go.id maupun e-mail dari Google dan Yahoo.

Saluran komunikasi yang digunakan kelompok melalui rapat Biro yang menghadirkan seluruh pegawai di Biro Fasilitasi Kebijakan Energi dan Persidangaan. Rapat setiap Bagian yang dihadiri oleh seluruh pegawai di lingkungan Bagian Humas dan Persidangan, Bagian Fasilitasi Kebijakan Energi dan Bagian Fasilitasi Rencana Umum Energi. Saluran komunikasi antar pribadi yang digunakan seperti melakukan komunikasi antar pribadi, seperti e-mail, telepon, WhatsApp, Short Message Service (SMS). Walaupun, SMS sudah tidak lagi populer, seperti aplikasi WhatsApp, namun masih digunakan untuk saluran komunikasi.

Kelima, efek yang diharapkan. Kepala Sub Bagian Keprotokolan menyampaikan bahwa pada dasarnya setiap pegawai sama, menginginkan keguyuban dalam Biro Fasilitasi Kebijakan Energi dan Persidangan. Walaupun terkadang beberapa ego pegawai muncul, namun masing-masing pegawai mempunyai rasa saling memiliki.

Protokol menyampaikan bahwa dengan rapat bersama tersebut dapat membuat setiap pegawai ikut dan saling berfikir untuk menghasilkan outcome yang lebih baik. Sementara, Kepala Sub Bagian Humas menyampaikan bahwa masyarakat menjadi mengetahui kebijakan disampaikan, sehingga masyarakat mengetahui hak dan kewajiban.

Berdasarkan hasil wawancara yang dilakukan kepada Kepala Biro Fasilitasi 
Kebijakan Energi dan Persidangan, Kepala Bagian Fasilitasi Rencana Umum Energi, Kepala Sub Bagian Penyediaan Energi, Kepala Sub Bagian Dokumentasi, Kepala Sub Bagian Keprotokolan, Kepala Sub Bagian Humas, Pengadministrasi Data dan Protokol, serta observasi dan peninjauan literatur dalam penelitian yang telah dilakukan dalam menjawab iklim komunikasi organisasi dan strategi komunikasi di Biro Fasilitasi Kebijakan Energi dan Persidangan Setjen DEN, akan dijabarkan di bawah ini.

Penelitian ini pada dasarnya bertujuan untuk menemukan jawaban mengenai iklim komunikasi organisasi dan strategi komunikasi di Biro Fasilitasi Kebijakan Energi dan Persidangan Setjen DEN. Berdasarkan analisa iklim komunikasi organisasi di Biro Fasilitasi Kebijakan Energi dan Persidangan sudah berjalan, walaupun strategi komunikasi Biro Fasilitasi Kebijakan Energi dan Persidangan belum dijalankan dengan konsisten

Penelitian terdahulu Harivarman, (2016: 513) menjelaskan adanya perbedaan persepsi antara pimpinan dan bawahan terhadap pelaksanaan kegiatan dan program, terbatasnya praktik sharing informasi dari pihak manajemen kepada pegawai pelaksana dan pengaruh gaya kepemimpinan atasan dalam pelaksanaan kegiatan dalam organisasi. Perbedaan persepsi pada Biro Fasilitasi Kebijakan Energi dan Persidangan tidak terlihat pada pelaksanaan tugas dan fungsi, namun lebih kepada beberapa individu yang belum dapat bekerja sama dalam tim secara maksimal, namun keterbatasan sharing informasi dari pimpinan kepada pegawai di bawahnya yang memang belum berjalan secara teratur. Adapun gaya kepemimpinan sudah dirasakan baik, agar iklim komunikasi organisasi dapat menjadi guyub. Sehingga, pelaksanaan tujuan organisasi yaitu tugas dan fungsi dapat berjalan dengan maksimal.

Penelitian Hambali; dkk, (2018: 107) menjelaskan alur komunikasi secara formal dalam organisasi tertata secara teratur dan mengikuti prosedur yang telah berlaku. Pola komunikasi yang dalam penyebaran informasi juga terjalin secara langsung dengan adanya feedback dari setiap penerima pesan. Selain itu, dari pola komunikasi yang terbentuk akan membuat hubungan interaksi antar anggota akan tetap harmonis karena penyebaran informasi terjadi secara transparan dan tidak kaku. Alur komunikasi pada Biro Fasilitasi Kebijakan Energi dan Persidangan belum tertata secara teratur, tergantung adanya disposisi atau arahan pimpinan, sehingga perlu pengaturan lebih lanjut untuk pelaksanaan tugas dan fungsi secara maksimal, seperti pola rapat pekanan atau bulanan yang mengatur rencana dan evaluasi kegiatan.

Pola komunikasi dalam penyebaran informasi masih terbatas pada informasi yang disampaikan dalam aplikasi WhatsApp dan aplikasi internal Nadine, walaupun lebih sering menggunakan aplikasi WhatsApp karena realtime dan lebih cepat. Selain itu, dari pola komunikasi yang sudah terbentuk saat ini, Biro Fasilitasi Kebijakan Energi dan Persidangan masih terkotak-kotak, sehingga memerlukan pola komunikasi yang "mencairkan" ketegangan (kotak-kotak) antar Bagian, sehingga ada perasaan saling memiliki dan guyub, dengan pertemuan yang lebih rutin dan sesekali mengadakan acara luar kantor seperti outbond serta pemberian reward and punishment dijalankan dengan tertib sesuai pegawai yang berprestasi dan pegawai yang indisipliner.

Penelitian Purnomo (2018: 24) mengungkapkan bahwa pelaksanaan kebijakan komunikasi organisasi pada Pemerintahan di Indonesia tidak terlepas dari faktor-faktor yang menunjang dan menghambat. Faktor tersebut adalah faktor pimpinan, tingkah laku pegawai, kelompok kerja, dan eksternal organisasi. Pada Biro

Fasilitasi Kebijakan Energi dan Persidangan faktor yang menunjang adalah faktor pimpinan dengan berusaha memberikan trigger untuk output pada organisasi dan memotivasi pegawai di bawahnya untuk memiliki dedikasi sebagai ASN. 
Sedangkan pada faktor yang menghambat yaitu Faktor tingkah laku pegawai ada beberapa pegawai saja yang cara berkomunikasinya tidak secara dua arah, sehingga mendominasi dan memerlukan koordinasi dengan pimpinan dan pegawai lainnya. Untuk faktor (tingkah laku) kelompok kerja perlu mendorong motivasi antar pegawai diperlukan pemberian reward, dan faktor eksternal organisasi bahwa dengan menurunnya anggaran dari tahun sebelumnya, tetap bekerja secara maksimal walaupun memiliki efek terhadap produktivitas kerja.

Penelitian (Ramadani, 2019a: 11) menjelaskan bahwa keterbatasan anggaran tidak mempengaruhi motivasi bekerja dan bahkan menjadi masukkan untuk lebih meningkatkan lagi dalam hal sinergi pengelolaan komunikasi publik ke depan. Keterbatasan anggaran pada Biro Fasilitasi kebijakan Energi dan Persidangan disikapi dengan bijak oleh pegawai, dengan pimpinan terus memberikan persuasi dan motivasi kepada pegawai agar tetap dapat bekerja secara maksimal. Selain itu, pimpinan mengingatkan dengan dedikasi sebagai ASN, sehingga semangat bekerja pegawai tetap ada untuk melaksanakan tugas dan fungsi organisasi dengan maksimal.

Penelitian yang dilakukan Pricahyadi \& Ramadani (2019: 112) menemukan bahwa strategi komunikasi sudah dilakukan, namun belum dijalankan dengan perencanaan yang sistematis. Begitu halnya dengan Biro Fasilitasi Kebijakan Energi dan Persidangan, strategi komunikasi sudah dilakukan, namun belum dijalankan dengan perencanaan yang sistematis. Sehingga efek yang diharapkan dalam strategi komunikasi yaitu keguyuban bekerjasama dalam tim agar pelaksanaan tugas dan fungsi dapat menghasilkan outcome yang lebih baik.

\section{PENUTUP}

Iklim komunikasi organisasi pada Biro Fasilitasi Kebijakan Energi dan Persidangan Setjen DEN diungkap bahwa pada faktor pimpinan, pimpinan memberikan motivasi kepada bawahan dan dengan dedikasi sebagai
ASN untuk menjalankan pekerjaan dengan baik. Pada faktor tingkah laku pegawai, masih terkotak-kotak antar generasi, antar Bagian, dan beberapa orang yang mendominasi belum berkomunikasi secara dua arah dengan baik. Pada tingkah laku kelompok kerja juga masih terkotak-kotak antar Bagian di lingkungan Biro Fasilitasi Kebijakan Energi dan Persidangan. Sedangkan, pada faktor eksternal organisasi, penurunan anggaran memiliki efek terhadap produktivitas kerja yang dihasilkan.

Pada strategi komunikasi, komunikator adalah pimpinan yang dapat mempersatukan seluruh pegawai, sehingga tidak terkotakkotak lagi. Target yang ditetapkan adalah seluruh pegawai di lingkungan Biro Fasilitasi Kebijakan Energi Persidangan. Pesan yang disusun berisikan mengenai kebijakan, yang dapat berupa arahan pimpinan, tindak lanjut hasil pembahasan rapat, sampai dengan peraturan perundang-undangan. Media yang digunakan aplikasi WhatsApp dan e-mail. Saluran komunikasi yang digunakan kelompok melalui rapat Biro, rapat Bagian, antar pribadi seperti e-mail, telepon, WhatsApp, dan SMS. Sedangkan efek yang diharapkan adalah keguyuban dalam Biro Fasilitasi Kebijakan Energi dan Persidangan.

Rekomendasi kebijakan yang dapat diterapkan ke depan adalah dengan melakukan rapat secara rutin terkait perencanaan dan evaluasi kegiatan, baik itu dalam lingkup Bagian maupun Biro, dan perlunya mencairkan kotak-kotak antar bagian dan pegawai serta pemberian reward bagi pegawai berprestasi dan punishment bagi pegawai yang indisipliner, sehingga pelaksanaan tugas dan fungsi organisasi dapat berjalan maksimal. Untuk penelitian ke depan, disarankan mendalami efektifitas komunikasi organisasi.

\section{DAFTAR PUSTAKA}

Atmaja, S., \& Dewi, R. (2018). Komunikasi Organisasi (Suatu tinjauan Teoritis dan Praktis). Inter Komunika Jurnal Komunikasi, 3(2), 192-206. 
Badrudin, S., Muslimin, \& Pratama, H. O. (2017). Analisis Komunikasi Organisasi di Pusat Informasi Haji Kantor Wilayah Kementerian Agama Provinsi Sumatera Selatan. JKPI: Jurnal Komunikasi Islam Dan Kehumasan, 1(2), 81-101.

Cangara, H. (2018). Perencanaan dan Strategi Komunikasi. Jakarta: Rajagrafindo Perkasa.

Erliana, H. (2005). Komunikasi Pemerintahan. Bandung: Refika Aditama.

Hambali, Muhaimin, A., \& Rahmadini, M. (2018). Pola Komunikasi organisasi Dalam Pengembangan program Studi Ilmu Komunikasi Fakultas Ilmu Sosial dan Ilmu Politik Universitas Islam Negeri Raden Fatah Palembang. Jurnal Studi Sosial Dan Politik, 2(2), 96-108.

Harivarman, D. (2016). Hambatan Komunikasi Internal di Organisasi. Jurnal ASPIKOM, 3(3), 508-519.

Hasyim, N. M. (2016). Komunikasi Organisasi di Perguruan Tinggi Islam Negeri (Studi Kasus di Fakultas Dakwah dan Komunikasi UIN Sunan kalijaga). Jurnal Promedia, II(2), 1-36.

Jumrad, O. T., \& Sari, I. D. M. (2019). Fungsi Komunikasi dalam Organisasi Melalui Group Chat Whatsup Oriflame Jurnal Common, 3(1), 104-114.

Khalid, I., \& Mukhtar, A. (2016). Energy Crisis: An Issue of Good Governance, A Way Forward. Journal of Political Studies, 23(1), 101-116.

Pricahyadi, M., \& Ramadani, T. (2019). Strategi Komunikasi Kebijakan pemerintah Provinsi DKI Jakarta Pada Peraturan Gubernur Nomor 110 Tahun 2018. Jurnal Ilmu Administrasi ( JIA ), XVI(1), 112-126.

Purnomo, A. (2018). Pelaksanaan kebijakan Komunikasi Organisasi Pemerintahan di Indonesia. Jurnal Noken, 3(2), 11-26.
Ramadani, T. (2019a). Implementasi Kebijakan Pengelolaan Komunikasi Publik di Kementerian Energi dan Sumber Daya Mineral. Jurnal Borneo Administrator, 15(1), 1-18.

Ramadani, T. (2019b). Pengelolaan Komunikasi Publik. Jurnal Good Governance, 15(1), 11-27.

Rodiah, S., \& Yusup, P. M. (2018). Strategi Komunikasi dalam Pengembangan Desa Agro Wisata di Kabupaten Pangandaran. Jurnal Signal Unswagati Cirebon, 6(2), 1-13.

Rosfiantika, E., \& Rodiah, S. (2015). Communication Strategies of Natural Resources and Environment Protection and Management Policies Based on Local Wisdom in Tasikmalaya Regency. Edutech, 1(2), 273-290.

Santoso, A. (2015). Iklim Komunikasi Organisasi di Hotel Savana Malang. Jurnal E-Komunikasi, 3(2), 1-8.

Santoso, R. (2017). Kebijakan Energi di Indonesia: Menuju Kemandirian. Jurnal Analis Kebijakan, 1(1), 28-36.

Sedarmayanti. (2018). Komunikasi Pemerintahan. Bandung: Refika Aditama.

Sugiarto, A., Priyowidodo, G., \& Indrayani, I. I. (2018). Iklim komunikasi organisasi di PT . Starindo Anugerah Abadi Surabaya Pendahuluan. Jurnal EKomunikasi, 6(2), 1-9.

Suparna, P., R, T. S., \& Winoto, Y. (2013). Keterbukaan Komunikasi dalam Menciptakan Iklim Komunikasi yang Kondusif di Perpustakaan. Jurnal Kajian Informasi Dan Perpustakaan, 1(2), 157-164.

Wijaya, I. S. (2013). Komunikasi Interpersonal dan Iklim Komunikasi dalam Organisasi. Jurnal Dakwah Tabligh, 14(1), 115-126 